\title{
Experimental Organism Malignant Thecoma
}

National Cancer Institute

\section{Source}

National Cancer Institute. Experimental Organism Malignant Thecoma. NCI Thesaurus.

Code C156613.

A malignant sex cord/stromal neoplasm characterized by densely packed fusiform theca cells arranged in interlacing bundles and whorls giving a nodular appearance. (INHAND) 